\title{
STUDIES ON PARTIAL AND COMPLETE REPLACEMENTS OF FISH MEAL WITH GAMBUSIA MEAL IN DIETS FOR THE COMMON CARP "CYPRINUS CARPIO"
}

\author{
Ali E. Abdelghany \\ Central Laboratory of Aquaculture Research, Abbassa, Abohamad, \\ Sharkia, Egypt.
}

Keywords: Fish meal replacement, Common carp, Gambusia, alternative protein source.

\begin{abstract}
Awelve week experiment was conducted to evaluate the Asuitability of gambusia (Gambusia affinis) fish meal (GFM) as a partial or complete substitute for the protein supplied by herring fish meal (HFM) in diets for the growth of common carp tingerlings (mean weight of $0.35 \mathrm{~g} / \mathrm{fish}$ ). Seven isonitrogenous (35\% crude protein), isolipidic ( $9 \%$ ) and isocaloric (3.7 kcal $\mathrm{DE} / \mathrm{g}$ ) diets werc formulated in which GFM replaced $0.0 \%, 10 \%, 25 \% 50 \%, 75 \%, 90 \%$. and $100 \%$ of the protein supplied by HFM. Results demonstrated that GFM has good potential as a substitute for up to $50 \%$ of the protein supplied by HFM in common carp diets with no significant $(\mathrm{P}<0.05)$ adverse effects on growth, feed efficiency, body composition and apparent digestibility of dry matter, protein and gross energy compared to fish fed the HFM-based diet (control diet). Survival rates in fish fed all the experimental diets were high and were statistically comparable to that of fish fed the control diet and ranged from $93.3 \%$ to $95.6 \%$. The percentages of apparent protein digestibility showed variation between diets, ranging from 81.1 to 86.6 with no significant differences among treatment means compared to the control diet. At the end of the study, substituting HFM-protein with GFM-protein in diets for common carp resulted in insignificant differences in final body composition of protein and ash, whereas dry matter and fat were significantly reduced $(P>0.05)$ compared to fish fed the control diet. Hematological characteristics of common carp were examined at the end of the study and the results showed that values of hemoglobin, $\mathrm{RBC}$, hematocrit and serum protein in fish groups of all the treatments were statistically equal or even better than those of fish fed the control diet. An economic analysis suggested the possibility of
\end{abstract}


using GFM as an altemative source of protein in common carp feed. Diets containing $50 \%$ of the protein from HFM and $50 \%$ from GFM provided the best economic efficiency of fish weight gain among all other test diets.

\section{INTRODUCTION}

Practical fish feeds are usually prepared from a variety of protein sources of vegetable and animal origins. Fish meal is traditionally the major animal protein source in fish diets but it is an expensive ingredient and it is necessary to look for acceptable substitute. In addition, the dwindling fish meal supply can no longer meet the expanding fish feed industry as a result of aquaculture development (Dong et al., 1993). Therefore, the search for alternatives to fish meal is an international research priority (Shiau et al. 1990; Chamberlain, 1993; Hardy and Kissil, 1997). Considerable emphasis has been given to the use of less expensive and equally efficient sources of protein. Several conventional oilseed meals, which have been used, include soybean, groundnut, cottonseed, and rapeseed meals (Jackson et al., 1982; Jauncey and Ross, 1982; Abel et al., 1984; Wilson and Poe, 1985). Ingredients of animal origin, which have also contributed to protein in fish feeds, include carthworms, housefly larvae, blood meal, feather meal, meat meal, single cell protein and krill (Spinelli $e t$ al., 1979; Tacon and Jackson, 1984).

Small-scale fish farmers in developing countries are constrained by both the availability and cost of pelleted fish feeds produced by the agro-industry. Hence, there is a need to encourage farmers to formulate their own pelleted feed using ingredients produced on-farm as far as possible; gambusia meal is one such ingredients. Gambusia affinis (also called the mosquito fish) is an exotic small fish, which was introduced as a biological mean to control mosquitoes. However, the effectiveness of Gambusia as a control agent remains unclear. In fact, the impact of Gambusia on mosquito populations has been minimal, because mosquito larvae form only a small part of their diet. They are no more effective at mosquito control than many native fish species and in fact the presence of Gambusia may actually encourage mosquito larvae, they may prey on the larvae's natural predators (e.g. dragonfly larvae) and also cause a reduction in the population of native fish that consume insect larvae (Milton and Arthington, 1982). Gambusia has 
established itself in warmwater bodies including rivers, lakes, ponds, creaks, canals, drainages, and swamps. It is an extremely hardy and adaptable fish, known to survive in a wide variety of temperatures and $\mathrm{pHs}$. It tends to remain stationary just below the water surface, using the relatively oxygen-rich interface layer. Females give birth to live young and produce several broods in warmwater with a gestation period of 21 to 28 days. These tiny fish are voracious surface feeders eating at the waterline with upturned mouths and can eat daily their own weight of a wide variety of prey ranging from aquatic insects and larvae to zooplankton. It is abundant in fish farms and is considered as a fish pest since it competes with native cultured fish for available food, dissolved oxygen and space. Gambusia is a rich source of animal protein ( $>55 \%$ as dry basis) but has no demand or money value in the market. No attempts have been made to use Gambusit: meal as a partial or complete substitute for fish meal although it may offer considerable potential for inclusion in feed for fish. Gambusia meal however requires examination as partial or complete substitute to the tradiiionally utilized fish meal of marine origin as part of the overall concept of formulating cheap feeds utilizing locally produced ingredients available "on-farm".

Common carp, Cyprinus carpio, is the predominantly cultured fish species in the world. It is an important commercial fish species in Egypt, and is used extensively in aquaculture. The objective of this investigation was to study the potential use of Gambusia meal as an alternative source to fish meal-protein in practical diets for the common carp.

\section{MATERIAL AND METHODS}

\section{Fish and Culture Technique}

Fry of common carp were obtained from a single nursery pond in the field station at the Central Laboratory of Aquaculture Research (CLAR), at Abbassa, Abohamad, Sharkia, Egypt. Prior to the start of the experiment, all fish were placed in a fiberglass tank where they were fed a commercial fish diet for two weeks as an acclimation period for laboratory conditions. The fish were then divided into 21 groups, each containing $30 \mathrm{fish}$ (average weight $0.35 \pm 0.006 \mathrm{~g} / \mathrm{fish}$ ). Each group of fish was transferred at random into an $80 \mathrm{~L}$ glass aquarium. Dechlorinated tap water was used throughout the study. In 
order to avoid accumulation of the metabolites, the water of the aquarium was changed daily. Each aquarium was also supplied with air produced by a central compressor. Water temperature and dissolved oxygen were recorded daily using a Model PENN-PLAX thermometer and Model YSI-55 oxygen meter, respectively. Other water quality parameters including $\mathrm{pH}$, ammonia and alkalinity were periodical measured using model CORNING-345 electronic $\mathrm{pH}$ meter; HACH colour comparator DRIL/5, and sulphuric acid titration method $(\mathrm{HACH})$ respectively. The photoperiod was set on a 12 hour light-dark cycle using fluorescent tubes as the light source.

\section{Gambusia Meal Preparation}

To produce Gambusia meal, Gambusia affinis, grown normally in fish ponds were

gathered from ponds in the experimental field station at CLAR, rinsed with water to remove residual soil and debris and oven-dried at $100^{\circ} \mathrm{C}$ for 24 hrs. The dried fish were ground, passed through a 595- $\mathrm{mm}$ mesh sieve, stored in air-tight plastic containers, and kept in a refrigerator at $4{ }^{\circ} \mathrm{C}$ until required for use in diet formulation.

\section{Diet Preparation and Feeding Regimen}

Seven diets were formulated to be isonitrogenous, isoenergetic, isolipidic and consideration was also given to the equivalence of other components such as fiber, ash and digestible energy. On average, the diets provided $35.4 \%$ crude protein and digestible energy contents of $3.7 \mathrm{kcal} \mathrm{DE} / \mathrm{g}$. The composition of the diets is shown in Table. (1) Diet-1 (control) contained herring fish meal (HFM) as a sole source of animal protein. Diet-7 contained Gambusia fish meal (GFM) as a sole source of animal protein. Diet 2 to 6 contained mixtures of HFM and GFM as sources of animal protein supplements with the proportions of each adjusted so that each of the two ingredients provided similar graded levels of animal protein in the diet. Graded levels of protein were $90,75,50,25$, and $10 \%$. All the diets contained a constant level of plant protein from soybean flour (SBF) to complete the protein requirements in the diets as determined by Ogino and Saito (1970). The chemical composition of HFM on dry weight basis was as follows: $72.27 \%$ crude protein, $11.44 \%$, crude lipid, $0.38 \%$ fiber, $11.36 \%$ ash, $4.55 \%$ NFE, and estimated digestible energy of $480.2 \mathrm{kcal} / 100 \mathrm{~g}$. The chemical composition of GFM on dry weight basis was follows: $55.77 \%$ crude protein, $10.63 \%$, crude lipid, $4.00 \%$ fiber, $25.09 \%$ ash, $4.51 \%$ NFE, and estimated digestible 


\section{STUDIES ON PARTIAL AND COMPLETE REPLACEMENTS OF FISH MEAL WITH GAMBUSIA MEAL IN DIETS FOR COMMON CARP}

energy of $390.26 \mathrm{kcal} / 100 \mathrm{~g}$. The chemical composition of SBF on a dry weight basis was: $51.42 \%$ crude protein, $1.85 \%$, crude lipid, $2.21 \%$ fiber, $5.53 \%$ ash, $38.99 \%$ NFE, and estimated digestible energy of $409.83 \mathrm{kcal} / 100 \mathrm{~g}$. The caloric value as digestible energy (DE) of each ingredient was estimated on the basis of $5 \mathrm{kcal} \mathrm{DE} / \mathrm{g}$ protein, $9 \mathrm{kcal} \mathrm{DE} / \mathrm{g} \mathrm{Lipid,} \mathrm{and} 3.49 \mathrm{kcal} \mathrm{DE} / \mathrm{g}$ of carbohydrate (Chiou and Ogino 1975). The dry ingredients of each diet (Table 1) were thoroughly blended in an electric mixer for about 20 minutes. The vitamin and mineral premixes were combined separately for 30 minutes in a twin shell chamber. Since HFM has higher lipid content and lower ash and fiber than GFM, $\alpha$-cellulose, oil and minerals (as sources of macro-elements $\mathrm{Ca}, \mathrm{P}, \mathrm{Na}$, and $\mathrm{K}$ ) were added in different, but calculated amounts in order to balance these nutrients at equal levels in all the experimental diets (Table1). Ethoxyquin, $150 \mathrm{mg} / \mathrm{kg}$ feed, was added to all the diets as an anti-oxidant. Water was gradually added to the dry mixture and blended for another 5 minutes. Pellets of $0.79 \mathrm{~mm}$ were made in a Sprout-Waldron laboratory pellet mill (CPM company, San Francesco, California). Each diet was cooled to room temperature and sifted by an electric sieve to separate the fine materials from the pellets. A portion of each formulated diet was also prepared to contain $0.5 \%$ chromic oxide, which was added in order to determine dry matter, protein and gross energy digestibility. All the test diets were prepared prior to the start of the trial. They were packed in sealed plastic bags and were kept frozen at $-10{ }^{\circ} \mathrm{C}$ until used. The experiment was started on August 11 and continued for 12 weeks. The test diets were fed to triplicate groups of fish. During the course of the experiment, all fish from each aquarium were collected every two weeks and collectively weighed. Feeding was carried out 7 days / week, 3 time / day and the ration was adjusted each time the fish were weighed. The feeding rate was $7 \%$ of fish body weight for the first eight weeks then reduced to $4 \%$ for the remaining period of the study because fish were getting bigger in size. The diets were analyzed using standard methods according to the Association of Official Analytical Chemists (AOAC 1990) for protein, fat, ash and moisture. Nitrogen content was measured by the Microkjeldahl method, crude protein was estimated by multiplying nitrogen value by 6.25 , lipid content was established by petroleum ether extract method, ash value was determined by igniting the samples in a muffle furnace at $550^{\circ} \mathrm{C}$ for 5 hours. Moisture content 
was estimated by heating samples in a forced air oven at $105^{\circ} \mathrm{C}$ for 24 hours and computing weight losses.

One method to estimate the nutritional value of dietary proteins is to determine their amino acid composition. In the present study, composition of the essential amino acids in the protein supplement ingredients, HFM, GFM and SBF, were measured (Table 2) by direct analysis using high pressure liquid chromatography (HPLC, Hewlett Packaed1090 II, Avondale, Pennsylvania, USA) using the described technique in Abdelghany (2000). The composition of essential amino acids in the test diets was estimated according to the proportions of the two ingredients in each diet and data are presented in (Table 2).

At the start of the experiment a sample of 50 fish of similar average body weight of experimental fish was taken and kept frozen. At the end of the experiment, two groups of fish, each of seven pooled samples of 12 fish (one sample / treatment and 4 fish / replicate) were randomly collected. The fish samples of the first group was also frozen and all the frozen samples were kept at $-20^{\circ} \mathrm{C}$ until later use for proximate chemical analysis of whole fish body for protein, fat, ash and moisture. The fish samples of the second group were anaesthetized with tricaine methanesulphonate (MS 222) and blood samples were collected in heparinized tubes by emulation of the caudal peduncle for analysis of hemoglobin, hematocrit, serum protein and red blood cell count as described by Wedemeyer and Yasutake (1977).

\section{Digestibility}

Directly after the termination of the substitution experiment, the fish rearing system and three hundred and fifteen fish were retained for the feces collection required for determination of dry matter, protein and gross energy digestibility of the experimental diets. The retained fish in each aquarium were equal in number $(15$ fish/aquarium) and bulk weight (ca. $60 \mathrm{~g}$ /aquarium). Fish were fed the corresponding diets, previously used in the substitution experiment but with $0.5 \%$ added chromic oxide (at the expense of cellulose in the diets) once a day in the morning to satiation for a period of three weeks. Feces were recovered from fish (treatment 1 to 7) used in the substitution study, after they had been adapted to the regimes for about 3 months: To be certain that the indicator- containing feed was present throughout the alimentary canal, the fish were allowed to feed on the chromic oxide diets for one week before any fecal samples 
were taken. De La Noue, et al. (1980) using trout, and Schmite, et al. (1984) using eel, found that feces from third day fully represented a given diet. Feces from each aquarium were removed by siphoning through fine mesh net and separately collected in individual jars (6 hours post feeding). The jars were immediately frozen to retard bacterial decomposition until later chemical analysis. Fecal samples were oven dried, ground and analyzed for moisture, crude protein, lipids and ash. Chromic oxide in diets and fecal samples were measured by acid digestion with concentrated sulfuric acid and perchloric acid following the procedure described by Zivkovic and Nowar (1977). Apparent digestibility coefficients were calculated using the classical formula of Maynard et al. (1979).

$\mathrm{mg} \mathrm{Cr} 2 \mathrm{O} 3 / \mathrm{g}$ diet \% protein in feces

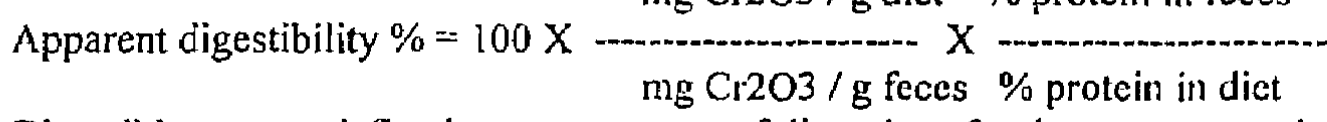

Digestible energy defined as gross energy of diet minus fecal energy was calculated by the following formula:

Apparent digestible energy $\%=$ energy of diet - energy of feces $X$

$\mathrm{mg} \mathrm{Cr} 2 \mathrm{O} 3 / \mathrm{g}$ diet $\mathrm{mg} \mathrm{Cr} 2 \mathrm{O} 3 / \mathrm{g}$ feces

\section{Statistical Analysis}

One-way analysis of variance was used to test the effects of the treatments on various growth and feed utilization parameters. Duncan's Multiple Range Test (Duncan, 1955) was applied to compare the significance of means of the various parameters among the tested treatments.

\section{Economical Evaluation}

The cost of feed to raise unit biomass of fish was estimated by a simple economic analysis. The estimation was based on local retail sale market price of all the dietary ingredients at the time of the study, which were all converted to US dollars. These prices (in $\$ / \mathrm{kg}$ ) were as follows: Herring fish meal, 1.006; Gambusia, 0.075; soya flour, 0.353 ; starch, 0.219; corn oil, 0.603 ; fish oil, 0.959 ; cellulose, 0.123 ; vitamin mixture, 9.589; mineral premix, 2.74; and additional minerals $\left(\mathrm{CaHPO}_{4}, \mathrm{NaCl}, \mathrm{KCl}\right), 0.055$. An additional $8.0 \%$ over the total raw 
material cost was included towards manufacturing cost, marketing expenses and operating margin.

\section{RESULTS}

All fish soon became accustomed to the experimental diets and were observed to feed actively throughout the duration of the snudy. Fish fed diets, in which GFM replaced up to $50 \%$ of the protein supplied by HFM (diet 2 to diet 4) showed growth performance in terms of final weight ( $g /$ fish), weight gain ( $g /$ fish), percent increase in weight and growth rate ( $g$ /day) that was comparable to fish fed HFMbased diet (Table 3). All fish groups fed diets containing GFM replacing up to $50 \%$ of HFM-protein (diet 2 to 4) had growth performance parameters significantly $(P<0.05)$ higher than those of fish fed diets containing GFM at level of replacements higher than $50 \%$ (diets 5 to 7) (Table 3). Partial or complete replacement of GFM for $\mathrm{ITFM}$ in all the experimental diets did not significantly influenced survivability of common carp. In general, survival rate in fish fed all the experimental diets was high and ranged from $93.3 \%$ to $95.6 \%$ (Table 3). Recorded fish mortalities did not appear to be related to the dietary treatments.

Fish fed diets, in which GFM replaced up to $90 \%$ of the protein supplied by HFM (diet 5 and diet 6) had similar fecd utilization efficiencies in terms of FCR and APU to fish fed the HFMbased dict (Table 4). Complete replacement of GFM for HFM-protein in common carp diets did not affect utilization efficiency of the diets in terms of FER or PER when compared to fish fed HFM-based diet (Table 4). Protein deposited in common carp ( $\mathrm{g} / 100 \mathrm{~g}$ of fish) fed GFM up to $50 \%$ level of replacement for HFM-protein was similar to that of fish fed the control diet.

Partial or complete replacement of GFM for HFM-protein in all the experimental diets did not significantly influenced apparent digestibility of dry matter, crude protein or energy (Table 4) where they all were comparable to those of the HFM-based diet.

The results of proximate analysis of whole body of common carp for protein, fat, ash and dry matter at the end of the study are shown in Table (5). Partial or complete replacement of GFM for HFM-protein in diets had no effects upon protein and ash levels. Dry matter and fat in fish fed diets contained GFM up to $50 \%$ levels of replacement for HFM-protein were comparable $(P>0.05)$ to those of fish fed the 


\section{STUDIES ON PARTLAL AND COMPLETE \\ REPLACEMENTS OF FISH MEAL WITH GAMBUSIA MEAL IN DIETS FOR COMMON CARP}

control diet. When GFM replaced more than half of HFM-protein, dry matter and fat were significantly $(P<0.05)$ reduced compared to the HFM-based diet.

Blood analysis data of common carp at the end of the study indicated that all values were in the acceptable limits for normal fish (Table 6). Partial or complete replacement of GFM for HFM in all the experimental diets did not significantly $(P>0.05)$ influenced red blood cell count (RBC). Values of hemoglobin $(\mathrm{g} / \mathrm{l} / 00 \mathrm{ml})$, hematocrit value $(\%)$ and serum protein $(\mathrm{g} / 100 \mathrm{ml}$ of blood) were all similar $(\mathrm{P}>$ 0.05 ) or even better than those values of fish fed the HFM-based dict.

The economic analysis showed that diets containing higher levels of GFM were cheaper than diets containing higher levels of HFM (Table 1). Fish fed diet, in which GFM replaced $50 \%$ of the protein supplied by HFM produced fish at lower cost per unit of weight value $(\mathrm{kg})$ compared to all other test diets (Table 3).

Values of water quality parameters ( temperature, dissolved oxygen, total ammonia, $\mathrm{pH}$, and total alkalinity) in aquaria varied during the study period from $26.3^{\circ} \mathrm{C}-28.1^{\circ} \mathrm{C} ; 6.8-7.7 \mathrm{mg} / \mathrm{l} ; 0.7-$ $0.9 \mathrm{mg} / \mathrm{l} ; 7.2-7.8$; and $250-301 \mathrm{mg} / \mathrm{l}$ respectively. All values were within the tolerance limits of warm-water fish species (Boyd, 1979) and had no significant differences $(P>0.05)$ among treatments.

\section{DISCUSSION}

In the present study, all fish fed actively on the experimental diets and grew and showed no external sign of nutritional deficiency for the duration of the study. These observations suggest that the diets contained all the necessary growth factors required by common carp. However, despite the isonitrogenous, isolipidic and isocaloric nature of the experimental diets, there was disparity in growth response of fish and efficiency of feed utilization (Table 3 ). This is clear from the relationship between substitution levels of GFM for the protein from HFM and average weight of individual fish at the end of the study (Table 3). Thus, there was an increase in average weight of common carp as GFM replacing protein from HFM rises to certain point up to $50 \%$ (diet-4) beyond which a reduction in average fish weight was observed (Table 3). The growth performance parameters of weight gain $(g / f i s h)$, percent increase in weight and growth rate $(g /$ day) had similar trends to that of the weight of fish at the end of the study. 
Several other experiments of fish meal-replacement in diets for common carp also illustrated growth reduction when all the fish meal was replaced by e.g. krill meal (Lukowicz, 1979); single cell protein (Ohmae et al., 1979) and soybean (Viola et al., 1983). Reduced growth following total substitution of fish meal has been reported for some fish and crustacean species, e.g., plaice, Pluronectes platessa (Cowey et al., 1971), tilapia, Oreochromis mossambicus (Jackson et al., 1982), rainbow trout, Salmo gairdneri (Dabrowski et al., 1989), channel catfish, Ictalurus punctatus (Webster et al. 1992), crustacean, Penaeus vannamei (Chhorn, 1996).

The results of nutrients digestiblity (Table 4) clearly indicate that protein from GFM is digested and utilized in a manner similar to protein from HFM, whereas dry matter and energy from GFM are as similarly and efficiently digested as the dry matter and energy from HFM. This finding indicates that GFM has potential as an alternative source of protein for HFM and its use in practical diets for common carp is feasible. However, partial or complete substitution of either animal or plant protein sources for fish meal has recorded variable success in practical fish feeding (Webster et al. 1992; Robinson and Meng, 1994; Belal and Assem, 1995; Chhorn, 1996; Webster, 1997 ).

The utilization of dietary protein is dependent upon its quantitative essential amino acid profile. The more closely the dietary protein meets the needs of the animal for essential amino acids, the greater will be its assimilation. The amino acid profile data indicated that apart from methionine, the essential amino acids as percentages of protein were greater in GFM than in HFM (Table 2). Also the percentages of essential amino acids in protein of all the formulated diets were equal or greater than the requirements for growth of common carp as reported by Nose (1979). In the case of methionine, the fish actually has a requirement for total sulfur amino acids. It was reported that cystine partially spares dietary methionine on a mmole sulfur basis at levels of $60 \%$ in channel catfish (Harding et al., 1977) and at levels of 50\% in Nile tilapia (Abdelghany, 2000). Therefore, in the experimental diets of the present study, the sum of methionine plus cystine exceeds the dietary need of common carp for total sulfur amino acids. In general, partial or complete repiacement of GFM for HFM-protein in the experimental diets for common carp in the present study resulted in dietary amino acid profiles that meet the requirements of the species studies. This result demonstrated that the amino acid profile of protein from GFM is as good as HFM and the quality of protein in terms of the quantitative essential amino acids of 
STUDIES ON PARTIAL AND COMPLETE,

both ingredients are similar. Several other ingredients of animal origin (e.g. feather meal, poultry by product meal and meat with bone meal) have been tested with various fish species as substitute ingredients for fish meal with variable success. The disadvantage of these ingredients compared to fish meal was that the essential amino acid contents and profile of these ingredients were inferior. The advantage of GFM used in the present study compared to these ingredients was that the analyzed essential amino acid concentrations of GFM were superior to the tabulated essential amino acid concentrations of these ingredients (NRC 1993).

The results of the digestibility trial (Table 4) successfully demonstrated the nutritive value of GFM as an alternative protein source for common carp. In general, the comparable values of apparent digestibility of dry matter, protein and gross energy in all tested diets to those of the control diet (Table 4), suggest that dry matter, protein and gross energy are as efficiently digested from GFM as from HFM by common carp. A comparison of the digestibility coefficient values of protein (from $81.1 \%$ to $86.6 \%$ ) and gross energy (from $69.0 \%$ to $73.2 \%$ ) by common carp in the present study (Tablc 4) with the digestibility coefficient values of some protein source ingredients tested with other fish species, indicated that they were in close proximity (e.g. Nengas et al., 1995; McGoogan and Reigh, 1996).

Although all the experimental diets in the present study had similar dry matter, protein and energy contents (Table 1) and digestibilities (Table 4), this equivalence in the nutrients did not result in similar growth performances in fish. Growth in fish fed diets containing GFM at higher than 50\% level of replacement for HFMprotein (diets 5, 6 and 7) was reduced compared to fish fed diets containing GFM at lower replacement levels. This finding can be attributed to one or more of the following factors: 1-common carp may require a particular amino acid balance in the diet for optimum growth (e.g. amino acid balance similar to that profile exist in diet 4) (Table 2). It has been reported that some adverse interaction may occur between amino acids when their concentrations' in the diet are imbalanced (NRC, 1993). 2- low availability of certain essential amino acids in GFM may result in deficient diets, which stressed fish at high inclusion levels of GFM. In particular lysine and methionine readily undergo changes during the processing of feedstuffs that may 
render them unavailable to fish. Although, these amino acids will be chemically measurable, they will not be biologically available (Cowey, 1978). 3- anti-nutritional substances may exist in GFM which stressed fish at high inclusion levels of replacement in the diets and resulted in growth retardations. 4- reduced palatability or attractiveness of the diets (which in turn cause reduced feed intake and fish growth), when GFM was used at high levels of replacement. In the present study, reduced feed intake and growth of fish fed diets contained GFM at high levels of replacement was observed and a positive correlation between feed intake and growth rate was found $(\mathrm{r}$ $=0.81 ; \mathrm{P}<0.01)$. These results are in support to the assumption that high inclusion levels of GFM in the diets will reduce their palatability to common carp. However, palatability of a fish-meal depends on its origin (species type, single or mixed) and processing technique (Ogino and Chen, 1973) as well as other components of the diet. It is known that the maximum inclusion levels of an ingredient in formulated diets will depend not only upon composition, digestibility and utilization efficiency but also upon its palatability. However, if the assumption of reduced growth performance in common carp at high inclusion levels of GFM in the diets is true, then, it may be feasible that improved growth performance could result with complete replacement of GFM for HFM in common carp feeds when palatability enhancers or attractants are used to counter depressed teed inlake. Further studies in this subject may be needed. This need has been recognized in various other fish meal replacement-studies (e.g. Stickney et al. 1996; Davis et al., 1995; and Kissil et al., 1997).

Analysis of fish body composition (Table 5) indicated no significant differences in crude protein or ash concentration compared to fish fed the control diet. These results indicated that partial or complete replacement of GFM for HFM-protein did not alter the nutritional value of the fish produced. The results also suggested that common carp efficiently ingested, digested, assimilated and utilized protein and minerals from GFM similar to HFM. However, dry matter and fat concentration were significantly $(\mathrm{P}<0.05)$ reduced compared to fish fed the control diet when more than half of HFM-protein was replaced by GFM in the diets (diets 5,6 and 7). This may have resulted due to the smaller size of fish fed those diets (Table 3). It has been reported that a direct relationship exists between fish size and lipid content (Lovern, 1938).

At the end of the study, hematological characteristics of common carp (Table 6) fed the experimental diets were all normal 
with no observable hematological elevations, these findings indicate that the GFM produced no overt physiological abnormalities. Red blood cell counts were not significantly $(P>0.05$ ) affected by the source of protein in the diets. Partial or complete replacements of GFM for HFM-protein in diets for common carp resulted in hematological measurements of blood hemoglobin, hematocrit and serum protein similar or even better than those of fish fed the control diet (Table 6). The highest concentrations of hemoglobin, hematocrit and serum protein were observed to simultaneously to exist in all fish groups which were fed diets containing GFM at 50\% level of replacement (diet 4). All these finding therefore, encourage further intensified efforts to partly substitute GFM for HFM component in practical and commercial fish feeds.

Economic evaluation showed that diets containing higher levels of GFM were cheaper than diets containing higher levels of HFM (Table 1). As GFM inclusion in the diets increased up to $50 \%$ level of replacement for HFM-protein, the cost of diet to produce $1 \mathrm{~kg}$ weight gain of common carp was gradually reduced. This cost was gradually increased with the increase of GFM inclusion in the diets, due to the decline in fish growth. Therefore, the benefit of cheaper feed cost was not sufficient to off-set the lesser income caused by reduction in fish yield when more than half of HFM-protein was replaced by GFM.

\section{CONCLUSION}

It can be concluded that GFM is a promising protein source for inclusion in common carp diets and it is feasible to use GFM as a substitute up to $50 \%$ of the protein supplied by HFM in a $35 \%$ protein-diet for common carp feeding with values for growth, feed utilization efficiency, body composition of protein and ash and digestibility of dry matter, protein and gross energy comparable to those exhibited for fish fed HFM-based diet. In addition, substitution of GFM for HFM-protein in the diets improved the economics by reducing costs of feeding. A further implication of the finding is that about $50 \%$ of the production cost in terms of fish meal could be saved for the procurement of the other production inputs in aquaculture. 


\section{ACKNOWLEDGEMENTS}

This study was financially supported by the International Center for Living Aquatic Resources Management (ICLARM). The author appreciates the assistances provided by Dr. Mohamed Hassan and Dr. Mohamed Yhia, at the fish nutrition at CLAR.

\section{REFERENCES}

Abdelghany, A. E. (2000). Replacement Value of Cystine for Methionine in Semipurified Diets Supplemented with Free Amino Acids for the Nile Tilapia "Oreochromis niloticus" Fry. In the $5^{\text {th. }}$ International Symposium on Tilapia Aquacult., Rio De Janeiro, Brasil, 3-7 September 2000.

Abel, H.; Becker, K.; Meske, C. and Fridrich, W. (1984). Possibiliries of using heat-treated full fat soyabean in carp feeding. Aquacult., 42: 97 - 108.

Association of Official Analytical Chemists (AOAC) (1990). Official Methods of Analysis, 13 th. ed. Washington, D.C., USA.

Belal, I. E. H. and Assem, H. (1995). Substitution of soybean meal and oil for fish meal in practical diets fed to channel catfish, Iclalurus punclatus (Rafinesque): effects on body composition. Aquacult. Res., 26: 141 - 145.

Boyd, C. E. (1979). Water quality in warm water fish ponds. Auburn Univ. Agricultureal Experiment Station, Auburn, Alabama.

Chamberlain, W. G. (1993). Aquaculture trends and feed projections. J. World Aquacult. Soc., 24: 19 - 29.

Chiou, J. Y. and Ogino, C. (1975). Digestibility of starch in carp. Bull. Jap. Sci. Fish., 4:465-466

Chhorn, L. (1996). Substitution of cottonseed meal for marine animal protein in diets for Penaeus vannamei. J. World Aquacult. Soc., 27 (4): $402-409$. 
Cowey, C. B.; Pope, J. A.; Adron, J. W.; Blair, A. (1971). Studies on the nutrition of marine flatfish: growth of the plaice, Pleuronectes platessa, on diets containing proteins derived from plants and other sources, Marine Biology.. 10: 145153.

Cowey, C. B. (1978). Protein and amino acid requirements of finfish. EIFAC Symposium. Finfish Nutrition and Feed Technology, Hamburg, June 1978. EIFAC/78/Symp. R./6.

Dabrowski, K.; Poczyczynski, P.; Kock, G.; Berger, B. (1989). Effect of partially or totally replacing fish meal protein by soybean meal protein on growth, food utilization and proteolytic enzyme activities in rainbow trout, Salmo gairdneri, New in vivo test for exocrine pancreatic secretion. Aquacult., 77: 29-49.

Davis, D. A.; Jirsa, D.; Arnold, C. R. (1995). Evaluation of soybean proteins as replacement for menhaden fish meal in practical diets for the red drum (Sciaenops ocellatus), J. world aquacult. Soc., 26: $48-58$.

De la Noue, J.; Choubert, G.; Pagniez, B.; Blanc, J. M.; Louquet, P. (1980). Digestibilite chez la truite arc-en-ciel (Samo gairdneri) lors de l'adaptation a un nouveau regime alimentaire. Canadian J. Fish. Sci., 37: 2218-2222.

Dong, F. M.; Hardy, R. W.; Haard, N. F.; Barrows, F. T.; Rasco, B. A.; Fairgrieve, W. T.; Forster, I. P. (1993). Chemical composition and protein digestibility of poultry by-product meals for salmonid diets. Aquacult., 116: $149-158$.

Duncan, D. B. (1955). Multiple-range and multiple F. tests. Biometrics, 11: 1 - 42.

Harding, D. E.; Allen, O. W.; Wilson, R. P. (1977). Sulfur amino acid requirement of channel catfish: L-methionine and Lcystine. J. Nutr., 107: 2031 - 2035. 
Hardy, R. W.; Kissil, G. W. (1997). Trends in aquaculture feeding. Feed Mix, 5: 31-34.

Jackson, J. G.; Capper, B. C.; Matty, A. J. (1982). Evaluation of some plant protein in complete diets for tilapia, Sarotherodon mossambicus. Aquacult., 27:97-109.

Jauncey, K.; Ross, B. (1982). A Guide to Tilapia Feeds and Feeding. Institute of Aquacult. Univ. of Stirling, Scotland.

Kissil, G. W. M.; Lupatsch I.; Higgs D. A.; Hardy R. W. (1997). Preliminary evaluation of rapeseed protein concentrate as an alternative to fish meal in diets for gilthead seabream (sparus aurala). Israel J. Aquacult., 49; 135-143.

Lovern, J. A. (1938). Fat metabolism in fishes. II. The peritoneal pancreatic and liver fat of the sturgeon (Acipenser sturio). Biochem. J., 26 (146)201: 1985-1988.

Lukowic', V. M. (1979). Experiences with Krill (Epuhausia superba Dana) in the diet for young carp (Cyprinus carpio L). EIFAC Symposium. Finfish Nutrition and Feed Technology, Hamburg, June 1978. EIFAC/78/Symp. R./6.

Maynard, L. A.; Loosli, J. K.; Hintz, H. F.; Wamer, R. G. (1979). Animal Nutrition, $7^{\text {th }}$ Edition, McGraw-Hill Book Company, New York, USA

McGoogan, B. B.; Reigh, R. C. (1996). Apparent digestibility of selected ingredients in red drum (Sciaenops ocellatus) diets. Aquacult., 141:233-244. 
Milton, D. A. and A. H. Arthington, (1982). Reproductive biology of Gambusia affinis holbrooki Baird and Girard, Xiphophorus helleri (Günther) and X. maculatus (Heckel) (Pisces; Poeciliidae) in Queensland, Australia. J. Fish Biol., 23: 23-41.

Nengas, I.; Alexis, M. N.; Davies, S. J.; Petichakis, G. (1995). Investigation to determine digestibility coefficients of various raw materials in diets for gilthead sea bream, Sparus auratus, L. Aquacult. Res., 26: $185-194$.

Nose, T. (1979). Summary report on the requirements of essential amino acids for carp. pp. 145-156, in "Finfisl N Nutrition and Fishfeed Technology". K. Tiews and J. E. Halver, eds. Berlin: Heenemann Gmbh.

NRC, (1993). Nutrient Requirement of Fish, National Rescarch Council. National Academy Press, Washington, D. C.

Ogino, C.; Chen, M. S. (1973). Protein Nutrition in Fish. III. Apparent and true digestibility of dietary protein in carp. Bull. Jap. Soc. Sci. Fish., 39:649 - 651 .

Ogino, C. and Saito, K. (1970). Protein Nutrition in Fish. I. The utilization of dietary protein by young carp. Bull. Jpn. Soc. Sci. Fish., 36:250-254.

Ohmae, H.; Suzuki, R.; Shimma, Y. (1979). Influence of single cell protein feeds on the growth and reproductivity of carp with reference to fatty acid composition. EIFAC Symposium. Finfish Nutrition and Feed Technology, Hamburg, June 1978. EIFAC/78/Symp. R./6.

Robinson, E. H.; Meng, H. L. (1994). Use of plant proteins in catfish feeds: replacement of soybean meal with cottonseed meal and replacement of fish meal with soybean meal and cottonseed meal. J. World Aquacult. Soc., 25 (2): 271 276. 
Schmite, O.; Greuel, E.; Pfeffer, E. (1984). Digestibility of crude protein and organic matter of potential sources of dietary protein for eels (Anguilla anguilla). Aquacuit., 41:21-30.

Shiau, S. Y.; Lan, S. F.; Yu, S. L.; Lin, A. L.; Kwok, C. C. (1990). Deffated and fullfat soybean meal as partial replacements for fish meal in tilapia (Oreochromis niloticus $\mathrm{X} O$. aureus ) diets at low protein level. Aquacult., 86: 401 407.

Spinelii, J. C.; Mannken, C.; Stemberg, M. (1979). Alternative sources of protein for fish meal in salmon diets. In J. E. Halver and K. Tiewes (eds). "Finfish Nutrition and Fish Feed Technology", Vol. II. Heeneman Verlagsgesellschatt, Mbtt., Berlin, pp. 131 - 214.

Stickncy, R. R.; Hardy R. W.; Koch, K.; Harrold, R.; Seawright, D. Massee, K. C. (1996). The effects of substituting selected oilseed protein concentrates for fish meal in rainbow trout, (Oncorhynchus mykiss) diets. J. World Aquacult. Soc., 27: $57-63$.

Tacon, A. G. J.; Jackson, A. J. (1984). Utilization of conventional and unconventional protein sources in practical fish feedsA review. Paper presented at the Symposium on Fish Feeding and Nutrition, Aberdcen. July 1984.24 pp.

Viola, S.; Mokady, S.; Arieli, Y. (1983). Effects of soybean processing methods on the growth of carp, Cyprinus carpio. Aquacult., 32:27-38.

Webster, C. D. (1997). Effects of replacing fish meal in diets on growth and body composition of Palmetto Bass (Morone saxatilis X M. chrysops). J. Appl. Aquacult., 7:((1)53-67.

Webster, C. D.; Tidwell, J. H.; Goodgame, L. S.; Yancy, D. H.; Mackey, L. (1992). Use of soybean meal and distillers grains with soulables as partial or total replacement of fish meal in diets for channel catfish, Ictalurus punctatus. Aquacult., 106: $301-309$. 
Wedemeyer, G. A. and Yasutake, W. T. (1977). Clinical methods for the assessment of the effects of environmental stress on fish health. U.S. Fish and Wildlife Service Technical Paper 89, Washington, D. C.

Wilson, R. P. and Poe, W. (1985). Effects of feeding soybean meal with varing trypsin inhibitor activities on growth of fingerling channel catfish. Aquacult., 46: 19-25.

Zivkovic, S. and Nowar, M. S. (1977). A simple modification for rapid and accurate determination of chromitum oxide used in digestibility trials. Vitterinaria, 26:2-3. 
Table 1: Formulation ( $\%$ of total) and the analyzed composition of experimental diets (as \% DM basis).

\begin{tabular}{|c|c|c|c|c|c|c|c|}
\hline \multicolumn{8}{|c|}{$\%$ replacement of GFM for protein supplied by HFM and corresponding diet numbers } \\
\hline & 0 & 10 & 25 & 50 & 75 & 90 & 100 \\
\hline Ingredients & 1 -control & 2 & 3 & 4 & 5 & 6 & 7 \\
\hline Fish meal (herring) & 13.84 & 12.46 & 10.38 & 6.92 & 3.46 & 1.38 & -- \\
\hline Gambusja meal & - & 1.79 & 4.48 & 8.97 & 13.45 & 16.14 & 17.93 \\
\hline Soybean flour & 48.62 & 48.62 & 48.62 & 48.62 & 48.62 & 48.62 & 48.62 \\
\hline Starch & 12.94 & 12.94 & 12.91 & 12.86 & 12.81 & 12.81 & 12.78 \\
\hline C'orn wil & 5.10 & 5.10 & 5.10 & 5.10 & 5.10 & 5.10 & 5.10 \\
\hline Cod liver oil & 1.42 & 1.38 & 1.33 & 1.26 & 1.17 & 1.12 & 1.09 \\
\hline$a-c c$ llulosc & 9.88 & 9.81 & 9.71 & 9.54 & 9.38 & 9.27 & 9.21 \\
\hline Vilamin mixture & 2.00 & 2.00 & 2.00 & 2.00 & 2.00 & 2.00 & 2.00 \\
\hline Mineral premix ${ }^{2}$ & 3.00 & 3.00 & 3.00 & 3.00 & 3.00 & 3.00 & 3.00 \\
\hline $\mathrm{NaCl}$ & - & - & 0.05 & 0.05 & 0.10 & 0.10 & 0.10 \\
\hline $\mathrm{KCI}$ & -- & 0.02 & 0.04 & 0.09 & 0.11 & 0.17 & 0.17 \\
\hline $\mathrm{Ca}\left[\mathrm{CO}_{4}\right.$ & 3.20 & 2.88 & 2.38 & 1.59 & 0.80 & 0.29 & - \\
\hline Total & 100 & 100 & 100 & 100 & 100 & 100 & 100 \\
\hline \multicolumn{8}{|l|}{ Analyzer composition } \\
\hline Moisture \% & 9.58 & 9.46 & 8.91 & 9.11 & 9.00 & 9.07 & 9.34 \\
\hline Prolein \% & 35.85 & 36.04 & 35.10 & 36.06 & $34.9 !$ & 34.97 & 35.22 \\
\hline $1 . \mathrm{in}: \mathrm{d} \%$ & 9.41 & 9.25 & 10.00 & 9.85 & 10.00 & 9.54 & 9.68 \\
\hline$A \operatorname{sh} \%$ & 10.12 & 10.09 & 9.98 & 11.03 & 9.93 & 10.81 & 10.55 \\
\hline Fiber\% & 11.44 & 11.10 & 10.98 & 11.23 & 11.34 & 10.96 & {$[0.87$} \\
\hline $\mathrm{NFE} * \%$ & 33.18 & 33.52 & 33.94 & 31.83 & 33.82 & 33.72 & 33.68 \\
\hline Estimated $\Gamma^{2} / \mathrm{E}^{4}$ & 94.4 & 94.7 & 91.4 & 94.9 & 91.2 & 32.4 & 92.5 \\
\hline Estinated GF as kcai/kg & 4722 & 4718 & 4748 & 4714 & 4746 & 4687 & 4709 \\
\hline Estimated DE as kual/kg & 3797 & 3804 & 3840 & 3800 & 3826 & 3784 & 3808 \\
\hline Cost $(\$ 1 / \mathrm{kg}$ diel & 0.759 & 0.743 & 0.719 & 0.679 & 0.639 & 0.616 & 0.600 \\
\hline
\end{tabular}

1- Vitamin premix (per kg of premix); thiamine, $2.5 \mathrm{~g}$; riboflavin, $2.5 \mathrm{~g}$; pyridoxine,

2.0g; inositol, $100.0 \mathrm{~g}$; biotin, $0.3 \mathrm{~g}$;

pantotheric acid, $100.0 \mathrm{~g}$; folic acid, $0.75 \mathrm{~g}$; para-aminobenzoic acid, $2.5 \mathrm{~g}$;

choline, 200.0g; nicotinic acid, $10.0 \mathrm{~g}$;

cyanocobalamine, $0.005 \mathrm{~g}$; a-tocopherol acetate, $20.1 \mathrm{~g}$; menadione, $2.0 \mathrm{~g}$; retinol

palmilate, 100,000 IU;

cholecalciferol, $500,000 \mathrm{IU}$.

2- Mineral premix (g/kg of premix): $\mathrm{CaHPO}_{4} .2 \mathrm{H}_{2} \mathrm{O}, 727.2 ; \mathrm{MgCO}_{4} .7 \mathrm{H}_{2} \mathrm{O}, 127.5$;

KCJ $50.0 ; \mathrm{NaCl}, 60.0$;

$\mathrm{FeC}_{6} \mathrm{H}_{5} \mathrm{O}_{7} .3 \mathrm{H}_{2} \mathrm{O}, 25.0 ; \mathrm{ZnCO}_{3}, 5.5 ; \mathrm{MnCl}_{2} .4 \mathrm{H}_{2} \mathrm{O}, 2.5 ; \mathrm{Cu}(\mathrm{OAc})_{2} . \mathrm{H}_{2} \mathrm{O}$,

$0.785 ; \mathrm{CoCl}_{3} .6 \mathrm{H}_{2} \mathrm{O}, 0.477 ; \mathrm{CaIO}_{3} .6 \mathrm{H}_{2} \mathrm{O}$,

$0.295 ; \mathrm{CrCl}_{3} .6 \mathrm{H}_{2} \mathrm{O}, 0.128 ; \mathrm{AlCl}_{3} .6 \mathrm{H}_{2} \mathrm{O}, 0.54 ; \mathrm{Na}_{2} \mathrm{SeO}_{3}, 0.03$.

3- $\mathrm{NaCl}$ ([FN:6-04-152), $\mathrm{KCl}$ (IFN: 6-03-755) and ( $\left.\mathrm{CaHPO}_{4}\right)$ (IFN: 6-28-335) were added to adjust

the macromincrals $\mathrm{Na}, \mathrm{K}, \mathrm{Ca}$ and $\mathrm{P}$ in all the diets.

4- $\mathrm{P} / \mathrm{E}$ ratios were estimated as protein $(\mathrm{mg}) / \mathrm{kcal}(\mathrm{g})$ in gram diet. 


\section{STUDIES ON PARTIAL AND COMPLETE REPLACEMENTS OF FISH MEAL WITH GAMBUISA MEAL IN DIETS FOR COMMON CARP}
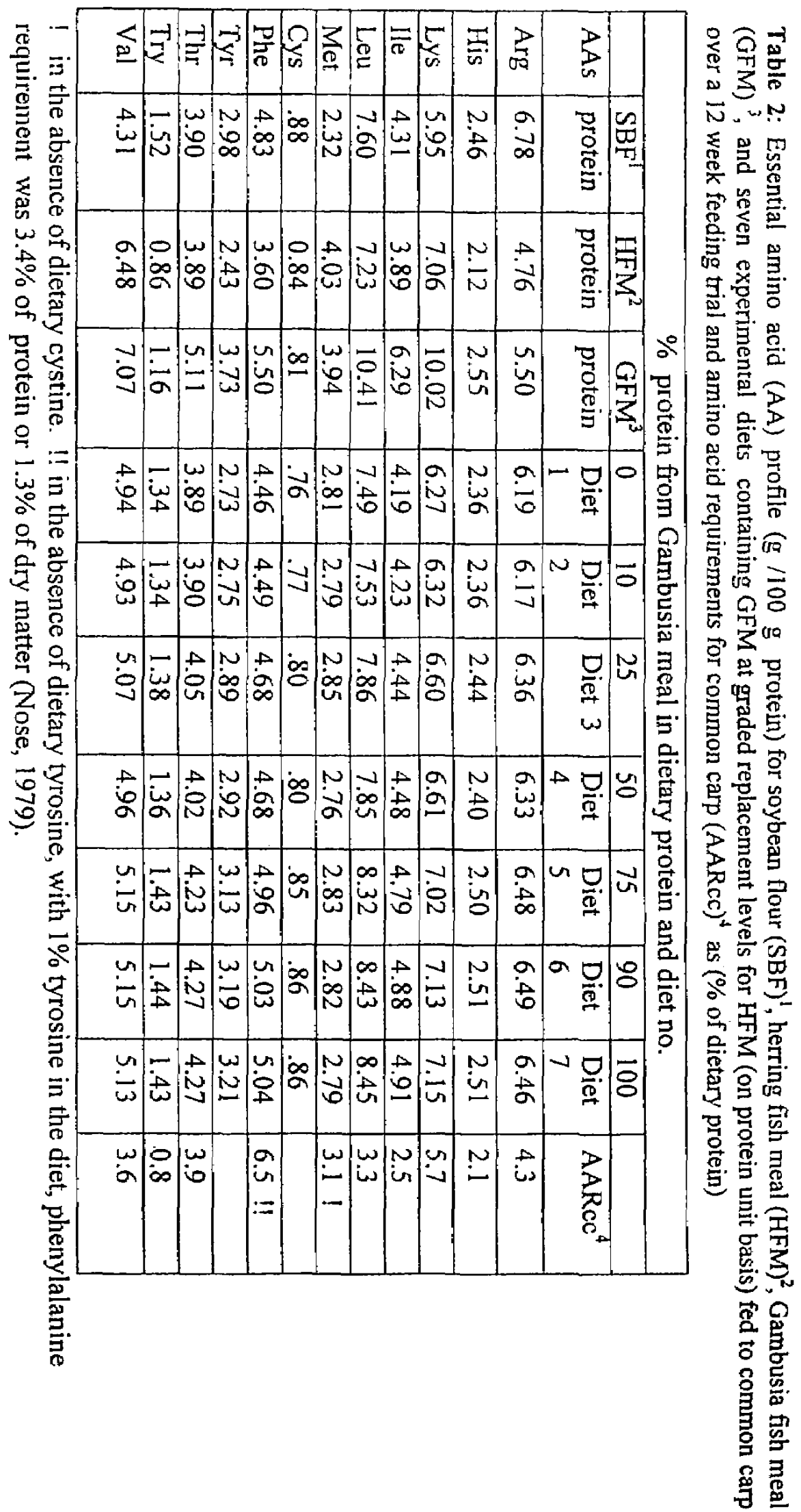


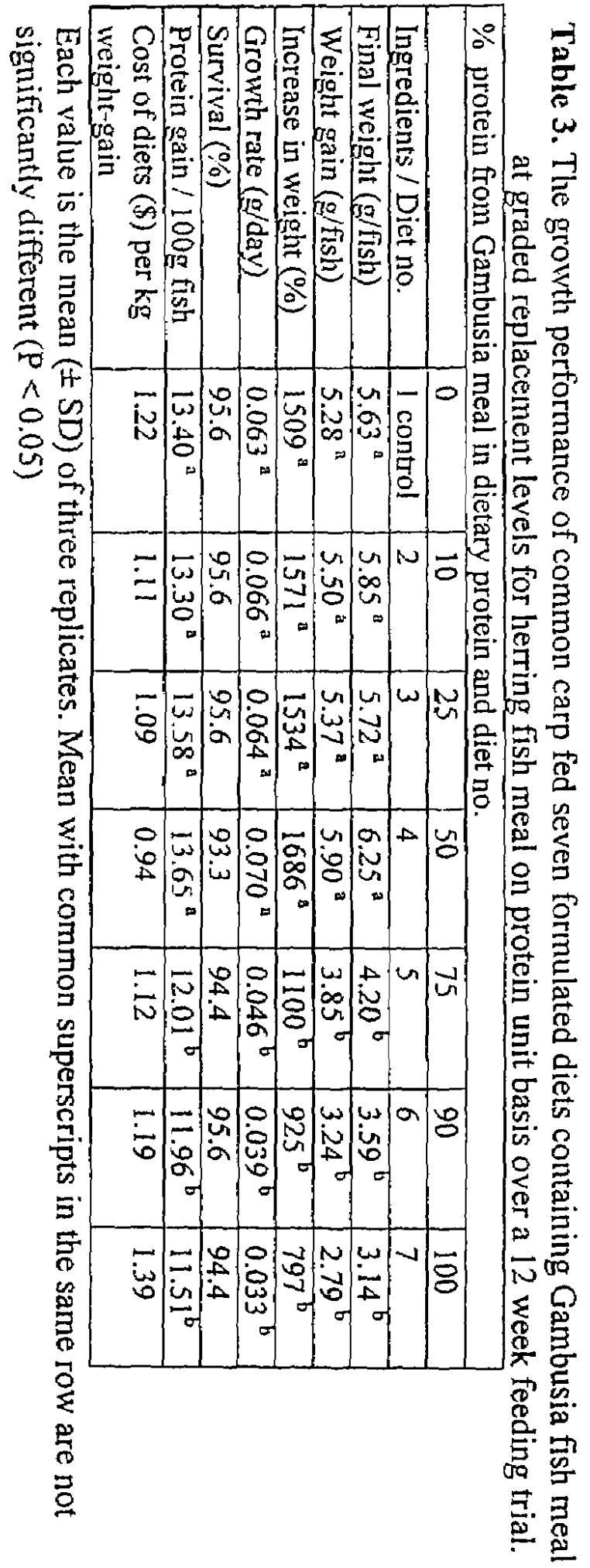




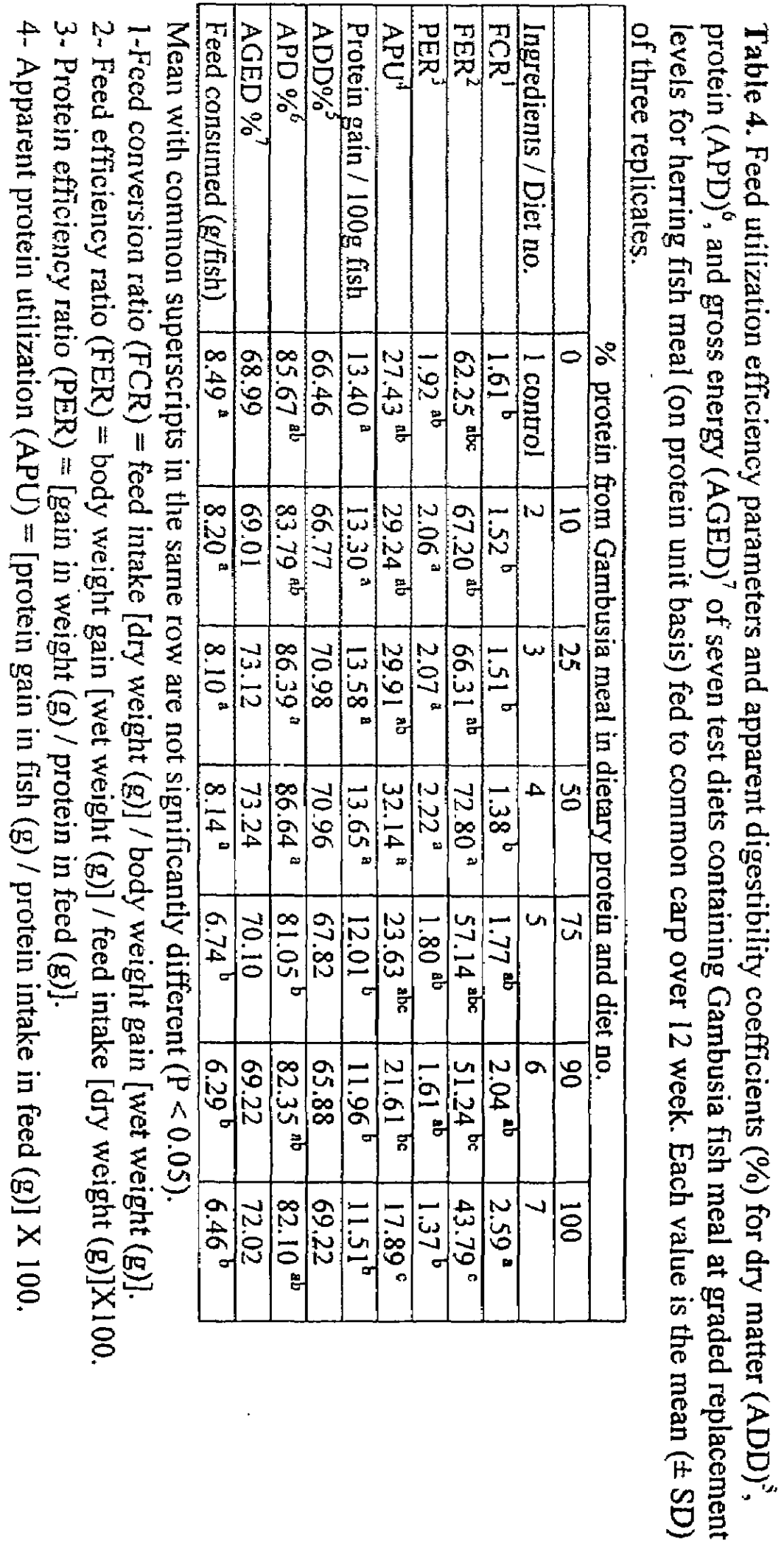






